\title{
Un-learn, de-grow, un-war
}

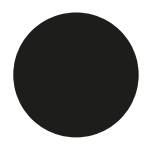

Armina Pilav, Un-war prostor, Galerija Greta, Zagreb,

25. veljače - 2. ožujka 2019.

DOI: 10.31664/zu.2019.104.12

Epistemološki sustavi koje gradimo danas kako bismo se suočili s posljedicama života u epohi antropocena, ili pak kako bismo imaginirali život u postantropocenu, motivirani su dvama temeljnim pojmovima: degrowth i unlearn. Dok je prvi nedavno (i pomalo nespretno) preveden kao „odrast”, drugi pojam uvriježen je u hrvatskom jeziku: „odučiti”. Ti pojmovi koji označavaju zaustavljanje, pa i mogućnost reverzibilnosti nekog procesa, baza su za modus operandi koji treba pokrenuti kako bi se zaustavila bezumna trka za profitom, ukorijenjena u mitologijama o povezanosti rasta proizvodnje i bruto nacionalnog dohotka s neizbježnim rastom potrošnje fosilnih goriva te navodnim boljitkom svakog pojedinca koji pristaje na takvu trku. Dok voze svoja motorna vozila koja bezočno gutaju benzin na svoja udaljena radna mjesta, pripadnici globalne srednje klase i tehnokracije svjesno zanemaruju činjenicu da globalne biopolitike „operiraju kao strateška igra u kojoj je princip rata asimiliran u samu potku društveno-ekonomskih i kulturnih mreža biopolitičkih odnosa". Takvi biopolitički odnosi uvjetuju stanje „krajolika koje podrazumijeva stalno pokretanje zemlje i ostalih prirodnih resursa u vojne svrhe”, 2 to je sam „etos rata”, ${ }^{3}$ odnosno „poredak običaja, civilizacije, misli, koji afirmiše rat, ne samo kao sredstvo jedne politike, nego i kao konsupstancijalni cilj ispoljavanja suverenosti, koji jedini ima izuzetno pravo".4$$
\text { Pilav, Un-war Lexicon. }
$$ 


\section{Un-learn, de-grow, un-war}

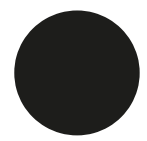

Armina Pilav, Un-war space, Greta Gallery, Zagreb

February 25 - March 2, 20I9

DOI: $10.31664 / z u .2019 .104 .12$

Epistemological systems which we build today, in order to face the consequences of life in the era of the Anthropocene, are motivated by two basic terms: degrowth and unlearn. While the first has been recently (and somewhat awkwardly) translated into the Croatian language as odrast, the second term has become habitual: oduciti. These terms that signify the stopping, and even the possible reversibility of a process, are the basis for the modus operandi that should be set in motion if we want to stop the mindless race for profit, which is rooted in the mythologies of the connection between production growth and gross national income with the unavoidable rise of fossil fuels consumption and the supposed betterment of all individuals who consent to this race. While driving their motor vehicles that shamelessly guzzle gas to their distant jobs, members of the global middle class and technocracy wilfully ignore the fact that global biopolitics "operates as a strategic game in which the principle of war is assimilated into the very weft and warp 1 of the socio-economic and cultural networks of biopolitical relations." ${ }^{1}$ Such bi- Hardt, Negri, Empire, 19. opolitical relations cause the "landscape condition of moving of the earth and 2 other natural recourses all the time for military purposes;" ${ }^{2}$ that is the very "ethos
of war," ${ }^{3}$ or rather the "disposition of manners, civilization, and thought that afof war," or rather the "disposition of manners, civilization, and thought that af-
firms war not solely as the means to a politics, but as an end consubstantial with the exercise of sovereignty, a sovereignty that in turn reserves for itself the excep- 4 tional right to wage war." ${ }^{4}$ 
Ako prihvatimo tu očitu činjenicu, logičan treći pojam koji se nadovezuje na degrowth i unlearn jest pojam unwar. Kao i pojam degrowth, pojam unwar teško je prevodiv. Biopolitičke determinante globalnog patrijarhata djeluju na način da je vrlo lako zaratiti, što podrazumijeva krenuti ili stupiti u rat, no ne dozvoljava po-imanje od-raćivanja. Ne postoji analogija glagolu od-učiti, jer možemo odučiti dijete od loše navike da nos briše rukavom, ali odučiti patrijarhalan svjetski poredak od profitabilnih ratovanja koja predstavljaju okosnicu tog poretka čini se gotovo nemogućim. ${ }^{5} \mathrm{U}$ članku „Un-War” umjetnik Krzysztof Wodiczko koncept pod tim imenom predstavlja „kao novo stanje svijesti koje omogućava proces razumijevanja, otkrivanja i opovrgavanja rata”. ${ }^{6}$

U svojem dugoročnom istraživanju Un-war prostor arhitektica Armina Pilav bavi se reprezentacijom kako prostora zahvaćenih ratom, s naglaskom na svoj rodni grad Sarajevo, tako i mogućnostima imaginacije un-war prostora. Jedan je od rezultata istraživanja izložba predstavljena i u Zagrebu u Galeriji Greta pod nazivom Un-war prostor od 25. veljače do 2. ožujka 2019. ${ }^{7}$ U središtu je izložbe kompaktni izložbeni uređaj ili, bolje rečeno, fukoovski dispositif, ili pak nansijevski techné, uz pomoć kojeg možemo misliti i osjećati stravičnu opsadu Sarajeva. Uređaj se tjelesnim angažmanom posjetitelja (pritiskom prsta, okretanjem ručice i sl.) transformira u neku vrstu performativnog arhiva, omogućavajući psihofizičku interakciju s materijalom, a time i pojačanu razinu doživljaja.

Doživljaja čega? Doživljaja Sarajeva koje je pod opsadom ${ }^{8}$ preživljavalo razdoblje od 5. travnja 1992. do 29. veljače 1996., dakle gotovo pune četiri godine. Doživljaja „načina na koje su civili doprinosili procesima opovrgavanja tokom rata u gradu Sarajevu i to kroz medij arhitekture”. ${ }^{9}$ Un-war prostor pokazuje „na koji su način interijeri i pojedinačni predmeti predstavljali adaptaciju nekog već postojećeg objekta ili predmeta, koji je djelomično promijenio svoj izvorni oblik i time poprimio novu i drugačiju upotrebu". ${ }^{10}$ Zoran Doršner ${ }^{11}$ i brojni drugi arhitekti, u nemogućnosti da grade, pa i promišljaju grad, preuzimali su ulogu dokumentarista, pri čemu se ideja građenja grada transformirala u „tranzicijski prostor pisanja ili ponovnog prisvajanja prostora". ${ }^{12} \mathrm{U}$ takvom se prostoru mijenjalo tjelesno iskustvo grada, kretanje gradom više nije moglo biti uspravno pa su tako civili u ratnom Sarajevu „uglavnom trčali od jednog do drugog mjesta, hodali pognuti i puzali po zemlji, zbog snajperske vatre, granatiranja i sirena za uzbunu". ${ }^{13}$ Što je s onima koji nisu mogli trčati ili puzati, povrijeđenima, ranjenima, ljudima s posebnim potrebama, roditeljima s malom djecom, starcima?! Bili su ograničeni na četiri krhka zida svojih stanova ili bolnica koji su u svakom trenutku mogli biti razneseni granatom.

Sve što se događalo u Sarajevu dokumentiralo se individualno i kolektivno, kako naglašava Pilav, starim medijskim formatima: tekstovima, telefaksom, fotografijama, crtežima, dnevnikom i videom. Danas su dokumentaristima na raspolaganju brojna druga sredstva poput web-mapiranja, 3D modela, interaktivnih stranica, tzv. pametnih telefona, uz društvene mreže i blogove koji omogućavaju instantno prenošenje informacija u one dijelove svijeta u kojima je život s internetskom vezom osnovna premisa rada i bitka. Međutim, to „teško da doprinosi našem razumijevanju načina adaptacije građana i građanki na ratne urbane uslove”. ${ }^{14}$

Upravo zato, uređaj koji je osmišljen u okviru projekta Un-war prostor odista je mašina koja omogućava kognitivni proces o preživljavanju u gradu pod opsadom, mašina koja emanira tu nevjerojatnu snagu ljudskog duha da nadjača ratnu mašinu koja je ipak prije svega globalnog karaktera i kojom se upravlja iz globalnih centara moći. Nakon što globalna ratna mašina negdje prividno stane, privatne militarističke kompanije preuzimaju ugovore o rekonstrukciji gradova, ${ }^{15}$ a kolonijalni centri moći poput New Yorka ili Londona preuzimaju rezerve nafte ili vode, ovisno o teritoriju, učvršćujući tako „monopol na nasilje” ${ }^{16}$ dok „,brutalno 'urbicidalno' nasilje i osiromašivanje često jača parazitske ekonomije gradova
5

Zanimljiv je test koji svatko može provesti na tzv. tražilici računala. Kako se svi uglavnom služimo pretraživačem Google, moguće je da ćemo dobiti i vrlo slične rezultate. Tako na računalu na kojem trenutačno nastaje i ovaj tekst upisom pojma war dobila sam 4510000 000 rezultata za 0,57 sekundi, dok sam upisom pojma peace dobila 1260000000 rezultata za 0,44 sekundi. Čak i takva jednostavna operacija ukazuje na strukturu odnosa u epohi planetarnog civilnog rata, kako u naslovu svoje knjige ističe Hito Steyerl. Vidi: Steyerl, Duty Free Art. Art in the Age of Planetary Civil War.

\section{6}

Pilav, Un-war Lexicon. Tekst Krzysztofa

Wodiczka „Un-War” objavljen je u magazinu Harvard Design 42 (2016.).

7

Uz Arminu Pilav, kustosko-istraživački tim projekta čine Ana Dana Beroš, Miodrag Gladović, Matija Kralj i Mauro Sirotnjak, a katalog pod nazivom Un-war Lexicon oblikovala je Rafaela Dražić.

\section{8}

Opsada je podrazumijevala konstantno granatiranje, redovita smaknuća snajperom građana koji su pokušavali živjeti, nabavljati ili uzgajati hranu, dobavljati vodu, dakle neviđen teror nad civilnim stanovništvom, masakr koji je ostatak svijeta pratio putem medija.

9 Pilav, Un-war Lexicon.

10

Isto.

11

U sklopu izložbe Sarajevo Dream and Reality koja je predstavljena u veljači 1995. godine u galeriji Parsons School of Design u New

Yorku, a koja je obuhvatila radove 14 sarajevskih arhitekata i studenata arhitekture kao svojevrstan „odgovor na destrukciju grada pod opsadom" (Ristić, Architecture, Urban Space and War, 125), arhitekt Zoran Doršner izložio je projekt pod nazivom Destruktivna metamorfoza iz 1994. godine, koji „sadrži skice, ilustrativne arhitektonske crteže stambene jedinice prije i nakon ratnih promjena, crteže civilne opreme za spašavanje i tekstove za izložbu i opise rada”. Tako Doršner „predstavlja složen analitički proces smrti grada, njegove rekonstrukcije, reprodukcije prostora i života u isto vrijeme". Izložba u Parsons School of Design pokazuje kako svijet ne samo da je medijski pratio rat u Sarajevu, svjestan svih užasa koji se tamo zbivaju, nego su i vodeće svjetske institucije bile itekako zainteresirane za načine preživljavanja u tom užasu, dodajući tako etosu rata (vidi bilješku 3) iskustvo „tijela za preživljavanje" i još jednu stranicu gusto ispisanu krvlju civila. Navodi iz: Pilav, Un-war Lexicon. 
If we accept this obvious fact, the logical third term that ties in with degrowth and unlearn is the notion of unwar. Same as degrowth, the concept of unwar is very difficult to translate. Biopolitical determinants of global patriarchy function in such a way that it is very easy to war, meaning to start or engage in a war, but do not allow for the concept of un-war. There is no analogy with the verb unlearn, because we can make a child unlearn a bad habit of wiping their nose on their sleeve, but making the patriarchal world order break the habit of waging profitable wars that represent the backbone of that order seems almost impossible. ${ }^{5}$ In the article "Un-War," artist Krzysztof Wodiczko presents this concept as "the new state of mind that enables the process of understanding, uncovering, and undoing war." ${ }^{6}$

In her long-term research project Un-war space, the architect Armina Pilav deals with the representation of places gripped by war, with an emphasis on her home town of Sarajevo, as well as the possibilities of imagining un-war spaces. One of the results of this investigation is the exhibition that was also presented in the Greta Gallery in Zagreb, between the February 25 and March 2, 20I9, under the title Un war space. At the centre of the exhibition is a compact exhibition apparatus or, put in a better way, a Foucauldian dispositif or maybe Nancy's techné, through which we can think and feel the horrific siege of Sarajevo. Through physical engagement of the visitors (pressing a finger, turning a handle, etc.), the device transforms into a kind of a performative archive, enabling a psycho-physical interaction with the material and thereby also an amplified level of experience.

Experience of what? The experience of Sarajevo which was under siege ${ }^{8}$ from the April 5, 1992 to the February 29, I996, meaning for almost four years. The experience of ways in which "civilians were contributing to the processes of undoing the war during the war in the city of Sarajevo through the medium of architecture." ${ }^{9}$ Un-war space shows "individual utilitarian objects as an adaptation of some already existing objects, partially changing their original shape and giving it a new and different use." ${ }^{10}$ Zoran Doršner ${ }^{11}$ and many other architects, unable to build and thus think about the city, took on the role of documentarists, thereby transforming the idea of the city into a "transitional space of writing or re-appropriation of spaces." 12 In such a space, the physical experience of the city changed: moving through the city could no longer be done upright so civilians "due to sniper fire, shelling, or warning sirens (...) usually ran from place to place, or else walked with a bowed 10 posture or crawled on the ground." ${ }^{13}$ What about those who could not run or crawl, Ibid. those who were hurt or wounded, people with special needs, parents with small children, the elderly?! They were restricted to four brittle walls of their apartments or hospitals, walls that could have been blown apart by a grenade at any moment.

Everything that happened in Sarajevo was documented individually and collectively by using, as Pilav points out, old media formats: texts, fax-machines, photographs, drawings, diaries and video. Today documentarists have at their disposal many other tools such as web-mapping, 3D models, interactive websites, so called smart phones, and of course social networks and blogs which enable in stantaneous transfer of information to those parts of the world where living with an Internet connection is the basic premise of working and being. However, this is "hardly contributing to our understandings of how citizens are adapting to wartime urban conditions." ${ }^{14}$

It is precisely for this reason that the device which was designed as part of the $U n$ war space project is truly a machine that enables a cognitive process on surviving in a city under siege, a machine that emanates that incredible strength of the human spirit that can overcome the war machine which possesses a global character and is controlled by the global centres of power. After the global war machine seemingly stops somewhere, private militaristic companies are awarded contracts for the reconstruction of cities, ${ }^{15}$ and colonial centres of power like New York or London take over the local reserves of oil or water, depending on the territory, and

\section{1}

5

There is an interesting test that anyone can do with their search engine. Since most of us use the Google search engine, it is possible that we will get very similar results. On the computer that I am currently using to write this text, I typed in the word "war" and got 4510000 ooo results in just 0.57 seconds, while the word "peace" resulted in I 260000 ooo results in 0.44 seconds. Even this simple operation indicates a structure of relations in the era of the planetary civil war, so called by Hito Steyerl in the title of her book. See: Steyerl, Duty Free Art. Art in the Age of Planetary Civil War.

6

Pilav, Un-war Lexicon. Text by Krzysztof Wodiczko "Un-War" was published in the journal Harvard Design 42 (20I6).

7

Besides Armina Pilav, the curatorial-research team of the project includes Ana Dana Beroš, Miodrag Gladović, Matija Kralj and Mauro Sirotnjak, while the catalogue called Un-war Lexicon was designed by Rafaela Dražić.

\section{8}

The siege meant constant shelling, regular executions by sniper fire of citizens who tried to live, get or grow food, get water, that is - an unseen terror over the civilian population, a massacre which the rest of the world followed through the media.

\section{9} Pilav, Un-war Lexicon.

As part of the exhibition Sarajevo Dream and Reality that was presented in February I995 at the Parsons School of Design Gallery in New York, and which included the work of I $_{4}$ Sarajevo architects and students of architecture as a kind of a "response to the destruction of the city under siege" (Ristić, Architecture, Urban Space and War, I25), the architect Zoran Doršner exhibited a project from I994 called Destructive metamorphosis that "contains working sketches, illustrative architecture drawings of a residential unit before and after wartime changes, drawings of the civilian rescue equipment, and texts for the exhibition proposal and explanation of the work." In this way, Doršner "represents a complex analytical process of the death of the city, its reconstruction, reproduction of space and life at the same time." The exhibition at the Parsons School of Design showed that the world not only followed the media coverage of the war in Sarajevo, aware of all the horrors that took place, but that the leading global institutions were very much interested in the methods for surviving those horrors, thus appending the ethos of war (see reference 3) with the experience of "survival bodies" and another page, densely written in the blood of civilians. Citations from: Pilav, Un-war Lexicon. 

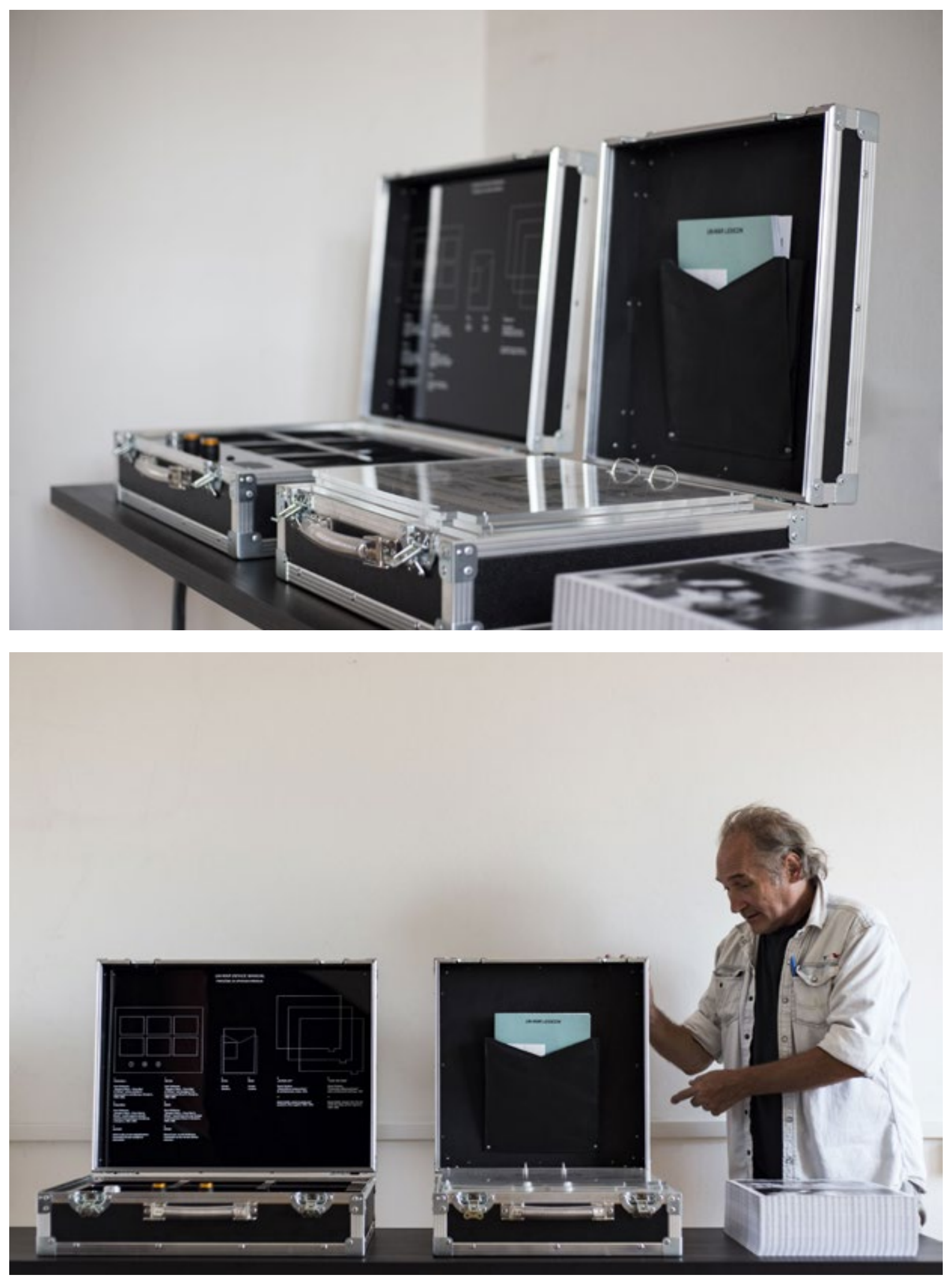

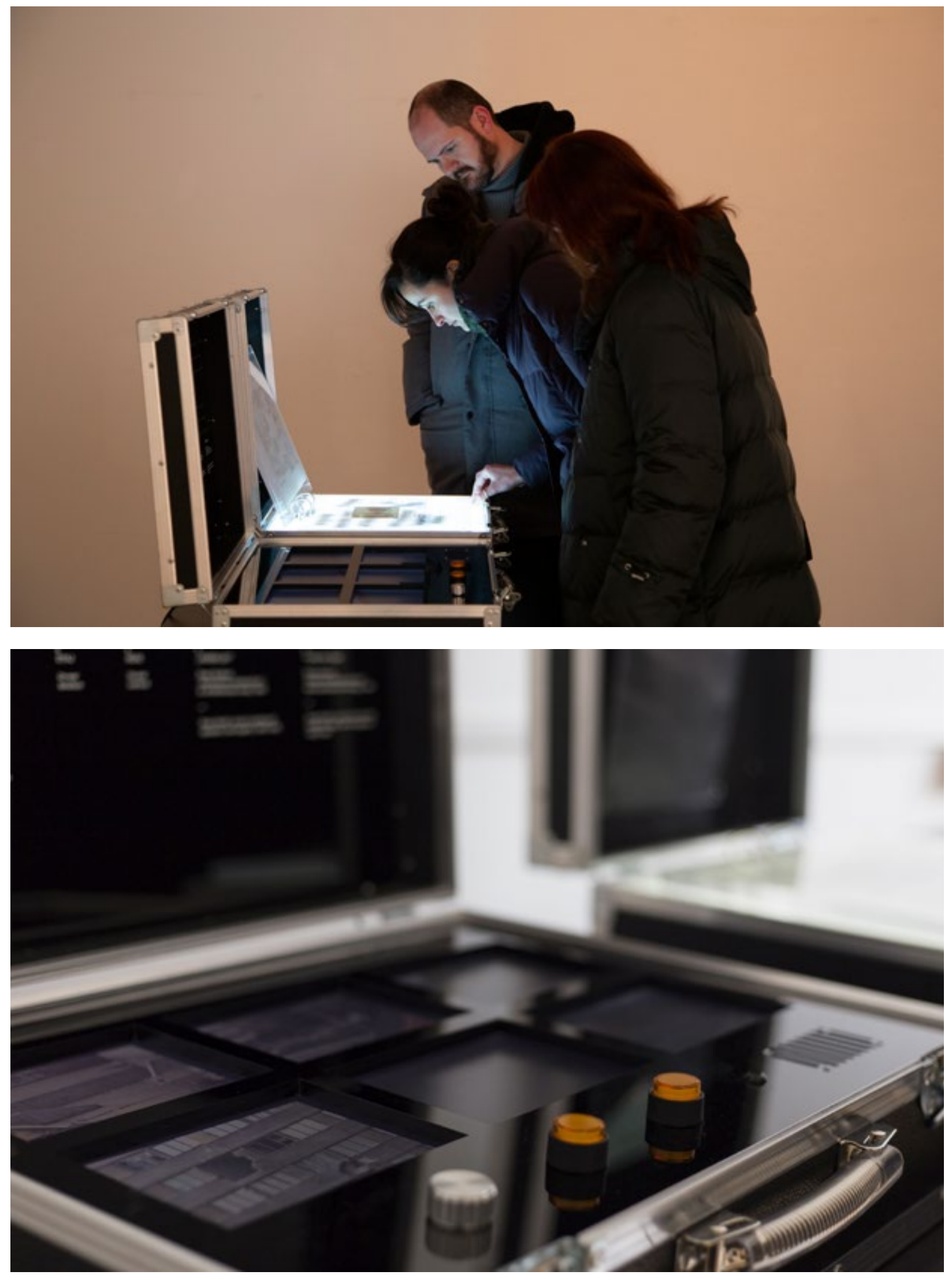

Armina Pilav, Un-war prostor/Un-war space. Foto/Photo: Matija Kralj. Ljubaznošću / Courtesy of Armina Pilav. $\leftarrow \uparrow$ 
Zapada, hraneći tako suvremeni korporativni kapitalizam” kao i „novi militari- Pilav, Un-war Lexicon. stički urbanizam koji je intimno povezan s neokolonijalnom eksploatacijom udaljenih resursa". ${ }^{17}$

13

Isto.

Un-war prostor, poučavajući nas što je rat, poučava nas i kako ga opovrgnuti, to 14 jest kako zamišljati svijet kojim ne upravlja ratna mašina. Un-war prostor didaktički je alat antimilitarističkog urbanizma.

Pilav, Un-war Lexicon

15

Graham, Cities under the Siege, xxviii.

16

Isto, xxiii.

17

Isto. 
thus consolidate the "monopoly of violence," ${ }^{16}$ while "brutal 'urbicidal' violence Pilav, Un-war Lexicon. and dispossession (...) helps bolster the parasitic aspects of Western city economies, as well as feeding contemporary corporate capitalism" as well as "the new 13 military urbanism [which] is thus linked intimately with the neocolonial exploitation of distant resources." 17

Teaching us a lesson on what war is, Un-war space also teaches us how to undo it, 15 or rather how to imagine the world that is not ruled by the war machine. Un-war Graham, Cities under the Siege, space is a didactic tool for anti-militarist urbanism. xxviii. 


\section{POPIS LITERATURE / BIBLIOGRAPHY}

Graham, Steven. Cities under Siege. The New Military Urbanism. New York: Verso, 2011.

Hardt, Michael, Negri, Antonio. Empire. Cambridge, MA: Harvard University Press, 2000.

Nancy, Jean-Luc. „Rat, pravo, suverenost-techné” [War, right, sovereignty-techné].

Beogradski krug 1-2 (1995.): 22-48.

„War, right, sovereignty-techné”, 28-58. U/In: Rethinking Technologies, ur./ed. Verena Andermatt Conley. Minneapolis: The University of Minnesota Press, 1993.

Pilav, Armina. Un-war Lexicon. Zagreb, 2018.

Ristić, Mirjana. Architecture, Urban Space and War: The Destruction and Reconstruction of Sarajevo. New York: Springer, 2018.

Steyerl, Hito. Duty Free Art. Art in the Age of Planetary Civil War. New York: Verso, 2017. 
